\title{
Archaeozoology of the Holocene multilayered site Ruchei Akimov (NW cis-Baikal Region, Russia)
}

\author{
Valeria V. Burova* \& Ekaterina D. Nikulina
}

\begin{abstract}
Preliminary data on faunal remains from the Holocene site Ruchei Akimov located in the Northern Angara region are presented. Cultural remains were found in three horizons. The goal of this study is to present new data on the archaeozoological collection excavated in 2011-2012. Altogether we recognized 11 taxa: Homo sapiens, Castor fiber, Canis familiaris, Ursus arctos, Martes zibellina, Equus sp., Cervidae gen. indet., Cervus elaphus, Capreolus pygargus, Alces sp., and Rangifer tarandus. This contribution focuses on archaeozoological treatment of the bones, including the measurements for bones identified to species, and description of bones modified by humans. The predominance of red deer and the presence of horse in the Neolithic - early Bronze Age are distinctive features of the site Ruchei Akimov. Bone remains with traces of human activity indicate hunting and fishery practiced in all periods of site use.
\end{abstract}

How to cite this article: Burova V.V., Nikulina E.D. 2019. Archaeozoology of the Holocene multilayered site Ruchei Akimov (NW cis-Baikal Region, Russia) // Russian J. Theriol. Vol.18. No.2. P.91-98. doi: 10.15298/rusjtheriol.18.2.03

KEY WORDS: archaeozoology, Middle - Late Holocene, Baikal Region, Russia.

Valeria V.Burova [valeria_29_05@mail.ru], Institute of the Earth Crust SB RAS, Lermontova str. 128, Irkutsk664033, Russia; Irkutsk State University, K. Marx str. 1, Irkutsk664003, Russia; Ekaterina D. Nikulina [katepiler@yandex.ru], Irkutsk State University, K. Marx str. 1, Irkutsk 664003, Russia.

\section{Археозоология голоценовой многослойной стоянки Ручей Акимов (северо-западное Прибайкалье, Россия)}

\author{
В.В. Бурова, Е.Д. Никулина
}

\begin{abstract}
РЕЗЮМЕ. Работа содержит предварительные сведения о костных остатках с неолитического местонахождения Ручей Акимов, расположенного в Северном Приангарье. Культурные остатки были зафиксированы в трех горизонтах. Цель исследования - представить новые данные об археозоологической коллекции, обнаруженной во время раскопочных работ 2011-2012 гг. В целом установлено 11 таксонов: Homo sapiens, Castor fiber, Canis familiaris, Ursus arctos, Martes zibellina, Equus sp., Cervidae gen. indet., Cervus elaphus, Capreolus pygargus, Alces sp. и Rangifer tarandus. В статье дано археозоологическое описание костных остатков, включая измерения костей, определенных до вида, и описание костей, модифицированных человеком. Преобладание благородного оленя и наличие лошади в неолите - раннем бронзовом веке являются отличительными чертами местонахождения Ручей Акимов. Костные остатки со следами человеческой деятельности свидетельствуют об охоте и рыболовстве, которые практиковались на протяжении всего существования стоянки.
\end{abstract}

КЛЮЧЕВЫЕ СЛОВА: археозоология, средний-поздний голоцен, Байкальский регион, Россия.

\section{Introduction}

The archaeological site Ruchei Akimov (Akimov Brook) is located on the right bank of the eponymous creek, at its confluence with the Angara River, $91 \mathrm{~km}$ downstream from the Ust-Ilim Hydroelectric Power Station (Northern Angara region) (Fig. 1). The site was discovered in 2007 during the rescue excavations in the area to be flooded after the construction of the dam of the Boguchany Hydroelectric Power Station. Protective and rescue archaeological works in 2011-2012 resulted

\footnotetext{
* Corresponding author.
}

in more than 20 thousand excavated items including 652 faunal remains.

Excavations revealed three conditionally defined horizons with archaeological and faunal material. Judging by the method of molding, technical decor and ornamentation, the ceramic complexes of the second and third horizons are typical for the Northern Angara region and adjacent territories. Their chronological range is estimated within the Neolithic period in the range of ca. 7800-3500 years ago (Tolstova, 2017). The concentration of stone arrowheads, found in 2012 and attributable to the second horizon by the characteristics of the manufacturing technique and 


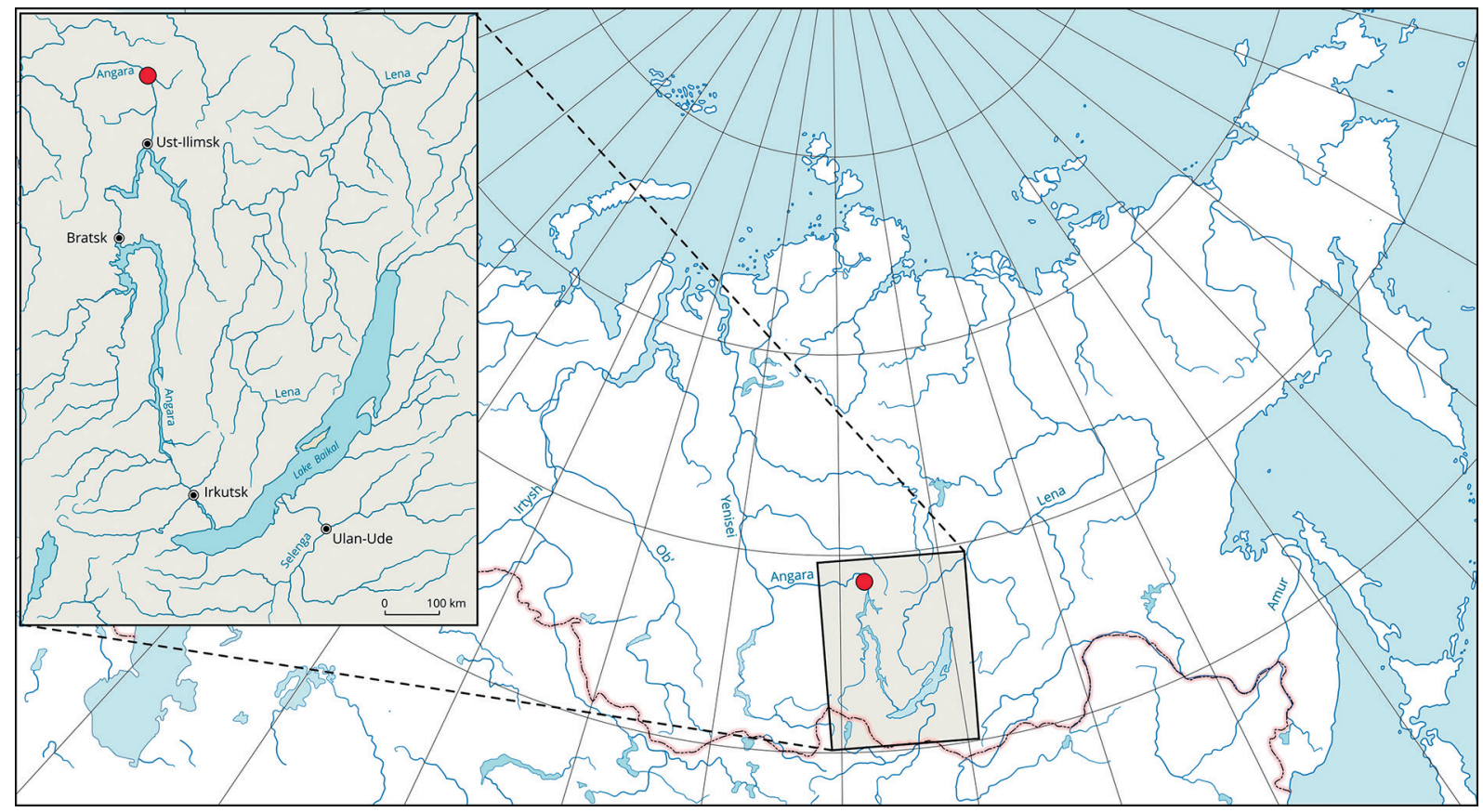

Fig. 1. Schematic map showing the location of the site Ruchei Akimov.

analogies from adjacent territories, corresponds to the regional Serovo Neolithic culture. Most probably it corresponds to the late Neolithic-early Bronze Age (Lyudnikov, 2012; Tolstova, 2016). The first horizon yielded strongly compressed material. It includes mixed material ranging from the late Bronze Age to the early Middle Ages.

\section{Material and methods}

In total, there are 652 animal bones, including 642 mammal bones, one avian bone and nine fish scales (Table 1). This study is based on bone remains excavated in 2011-2012. We count disintegrated bones with fitting parts and bones in anatomic groups as one specimen. The measurements (in $\mathrm{mm}$ ) follow the system of Von den Driesch (1976). Upper teeth are referred to as upper case letters (M1), lower ones, as lower case (m1).

Both authors identified bones to species and made archaeozoological treatment. All figures and measurements were made by Valeria Burova.

\section{Results}

\section{Chronological range of cultural horizons}

The first cultural horizon is represented by the smallest number of bones, $5.8 \%$ of all bones. Identifiable bones are rare $-13.5 \%$. They represent the following species: dog (Canis familiaris Linnaeus, 1758), horse (Equus Linnaeus, 1880), Cervidae gen. indet. (Cervidae Goldfuss, 1820), red deer (Cervus elaphus Linnaeus, 1758), moose (Alces Gray, 1821). There are also a burned fragment of the bone of a small mammal and fragments of bones of a large ungulate.

The largest number of bone remains was obtained from the second cultural horizon, $59.7 \%$. The percentage of identifiable bones in this layer is $8.6 \%$. The following taxa were found: human Homo sapiens Linnaeus, 1758 (3\%), beaver Castor fiber Linnaeus, 1758 (6.1\%), bear Ursus arctos Linnaeus, 1758 (9.1\%), sable Martes zibellina Linnaeus, 1758 (3\%), horse (3\%), Cervidae gen. indet. (15.2\%), red deer $(24.2 \%)$, roe deer Capreolus pygargus Pallas, 1771 (12.1\%), moose (21.2\%), reindeer Rangifer tarandus Linnaeus, 1758 (3\%). Among the indefinable bones, there are remains of small $(0.3 \%)$, medium $(26.3 \%)$, and large ungulates $(12 \%)$, as well as a small mammal $(0.6 \%)$.

The share of bones in the third cultural horizon is $34.6 \%$ of the total bone material. The percentage of identifiable bones is minimal, $4.1 \%$. The following taxa were found: beaver $(11.1 \%)$, bear $(22.2 \%)$, horse $(11.1 \%)$, roe deer $(33.3 \%)$, moose $(11.1 \%)$. Bones of medium size $(0.9 \%)$ and large ungulates $(12.2 \%)$ were recorded.

\section{Taxonomic composition of the assemblage}

Homo sapiens is identified by a burnt fragment of the distal end of the humerus. Due to the severe destruction, measurements could not be taken. More accurate chronological assessment of the bone will be possible after radiocarbon dating and isotopic analysis.

Four teeth and two ulnae represent the beaver. The teeth (lower right p4-m3) were found in the third cultural horizon and apparently belong to the same individual. The measurements were made on the chewing surface: the length and width of $\mathrm{p} 4-6.2 / 5.6$; the length and width 
Table 1. Taxonomic composition and remains counts in the site Ruchei Akimov.

\begin{tabular}{|l|c|c|c|c|}
\hline \multicolumn{1}{|c|}{ Taxon } & $\begin{array}{c}\text { First cultural } \\
\text { horizon }\end{array}$ & $\begin{array}{c}\text { Second cul- } \\
\text { tural horizon }\end{array}$ & $\begin{array}{c}\text { Third cultural } \\
\text { horizon }\end{array}$ & Total \\
\hline Homo sapiens & & 1 & & 1 \\
\hline Castor fiber & & 2 & 1 & 3 \\
\hline Canis familiaris & 1 & & & 1 \\
\hline Ursus arctos & & 3 & 2 & 1 \\
\hline Martes zibellina & & 1 & & 3 \\
\hline Equus sp. & 1 & 1 & 1 & 6 \\
\hline Cervidae gen. indet. & 1 & 5 & & 10 \\
\hline Cervus elaphus & 1 & 8 & 1 & 7 \\
\hline Capreolus pygargus & & 4 & 3 & 9 \\
\hline Alces sp. & 1 & 7 & 1 & 1 \\
\hline Rangifer tarandus & & 1 & & 1 \\
\hline Small ungulates & & 1 & & 94 \\
\hline Medium ungulates & & 92 & 2 & 75 \\
\hline Large ungulates & 7 & 42 & 26 & 3 \\
\hline Small mammals & 1 & 2 & & 422 \\
\hline Unidentified & 24 & 213 & 185 & 642 \\
\hline & 37 & 383 & 222 & 1 \\
\hline Aves & & 1 & & \\
\hline Pisces & & & & \\
\hline
\end{tabular}

of $\mathrm{m} 1-6.5 / 6.2$; the length and width of $\mathrm{m} 2-7.3 / 6.4$; the length and width of $\mathrm{m} 3-6.7 / 5.3$. Ulnae are represented by the right and left trochlear notch.

Dog is represented by the left mandibular ramus found in the first cultural horizon (Fig. 2). Angular and coronoid processes of the mandible are damaged. It was possible to obtain the following measurements: the total length of the mandible - 126.6; the length from the indentation between the condyle process and the angular process to the infradentale - 123.2; the length from the condyle process to the aboral border of the canine alveolus - 111.4; the length from the aboral border of the alveolus of $\mathrm{m} 3$ to aboral border of the canine alveolus measured along the alveoli - 73.7; length of the $\mathrm{m} 3-\mathrm{p} 1$ measured along the alveoli -68.8 ; length of the m3-p2 measured along the alveoli -64.9 ; length of the $\mathrm{m} 3-\mathrm{m} 1$ measured along the alveoli -35.1 ; length of the p1-p4 measured along the alveoli - 34.6; length of the $\mathrm{p} 2-\mathrm{p} 4$ measured along the alveoli -29.6 ; length of the alveolus of $\mathrm{m} 1-20.1$; greatest thickness of the body of mandible (below $\mathrm{m} 1$ ) -22.8 ; height of the mandible behind $\mathrm{m} 1-23.4$; height of the mandible between $\mathrm{p} 2$ and $\mathrm{p} 3-18.2$. A comparison of these measurements to those of Vulpes vulpes from Irkutsk region, Buryatia, and Yakutia showed that fox mandibles are smaller than the examined mandibular ramus. Fox mandibles have the following measurements: the total length of the mandible - 105.1, 101.4, 112.1; the length from the indentation between the condyle process and the angular process to the infradentale -99.8, 96.2, 106.8; the length from the condyle process to the aboral border of the canine alveolus- 93.5, 89.3, 98.4; the length from the aboral border of the alveolus of $\mathrm{m} 3$ to aboral border of the canine alveolus measured along the alveoli -67.5 , $59.7,65.5$; length of the $\mathrm{m} 3$-p 1 measured along the alveoli $-62.9,58.3,61.6$; length of the $\mathrm{m} 3-\mathrm{p} 2$ measured along the alveoli $-57.7,53.2,57.0$; length of the $\mathrm{m} 3-\mathrm{m} 1$ measured along the alveoli $-28.1,25.8,26.8$; length of the $\mathrm{p} 1-\mathrm{p} 4$ measured along the alveoli $-34.8,35.4,32.8$, 33.7; length of the p2-p4 measured along the alveoli $-30.0,30.3,27.9,29.2$; length of the alveolus of $\mathrm{m} 1$ $14.1,15.0,14.5,15.4$; greatest thickness of the body of mandible (below m1) - 15.5, 16.7, 14.4, 15.8; height of the mandible behind $\mathrm{m} 1-14.2,13.6,15.3$; height of the mandible between $\mathrm{p} 2$ and $\mathrm{p} 3-12.2,14.3,11.9,14.3$. The alveoli features indicate that development of the dentition in the mandibular ramus from Ruchei Akimov was completed. Therefore, the mandibular ramus cannot be from a young wolf. Thus, the mandibular ramus belongs to Canis familiaris.

Remains of a brown bear are represented by five teeth (Fig. 2). The following measurements were obtained: the height of the canine crown -30.5 and ca. 31.5; the length of the canine at the base of the crown - 19.0, ca. 19.1, 18.0; the width of the canine at the base of the crown - 14.0, ca. 13.3, 14.7. Roots are damaged in all 


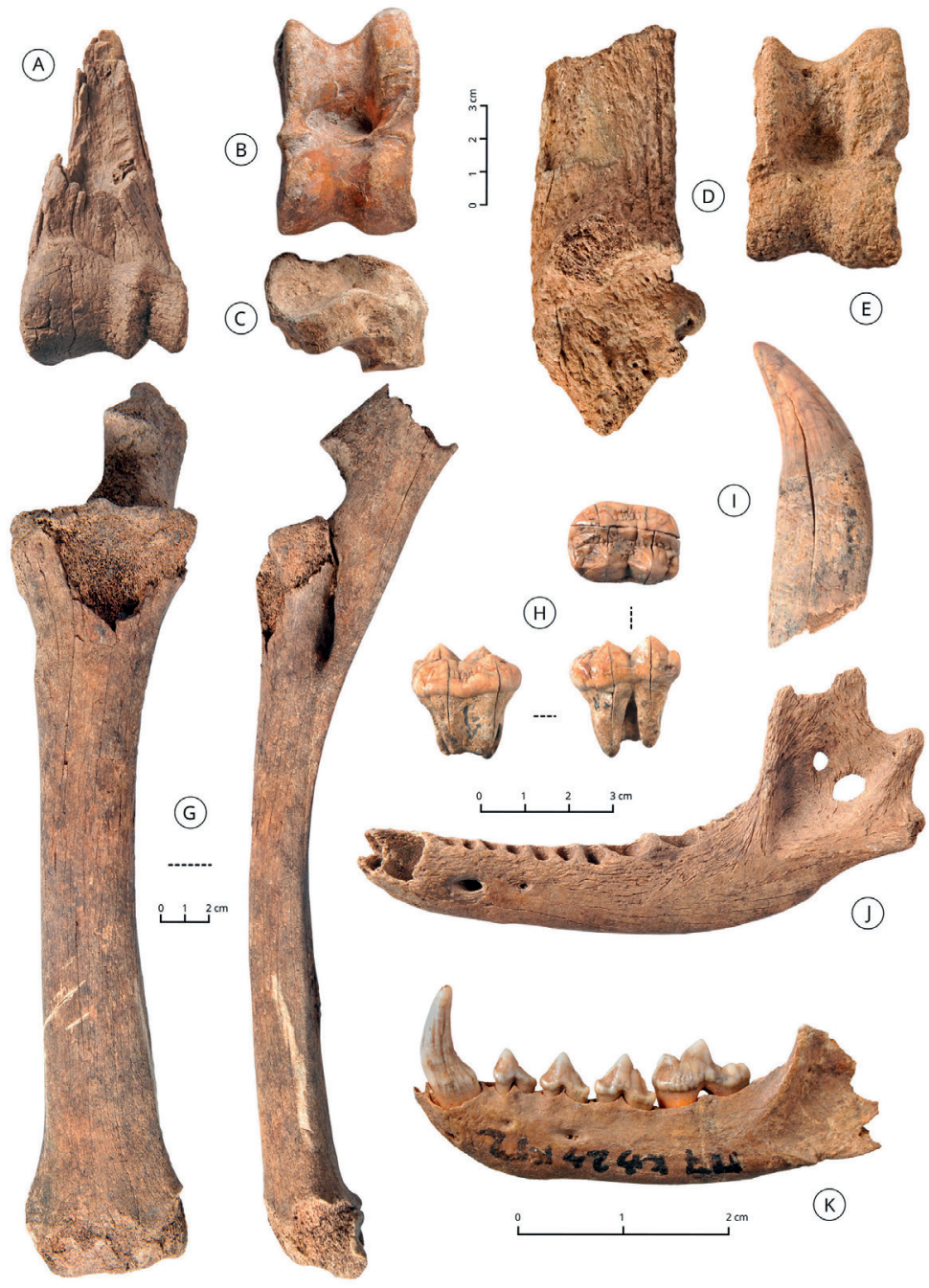

Fig. 2. Holocene bone remains from Ruchei Akimov. A - the humerus of Rangifer tarandus, cranial view; B - the astragalus of Cervus elaphus, dorsal view; C - the naviculo-cuboid of Cervus elaphus, dorsal view; D - the calcaneus of Cervus elaphus, dorsal view; $\mathrm{E}$ - the astragalus of Cervus elaphus, dorsal view; $\mathrm{G}$ - radial and ulnar bones of Equus sp., dorsal and lateral views; H - M1 of Ursus arctos, lingual, labial and occlusal views; I - the canine of Ursus arctos; J - the left mandibular ramus of Canis familiaris, labial view; $\mathrm{K}$ - the left mandible of Martes zibellina, labial view.

canines precluding the measurement of their total length. Length and width of M1 - 24.9/18.0.

Sable is represented by the left mandible with a canine and $\mathrm{m} 1-\mathrm{p} 2$ ( $\mathrm{m} 2$ and $\mathrm{p} 1$ are absent) and a fragment of the right mandible with an incomplete canine (Fig. 2). The left mandible has the following measurements: length of $\mathrm{m} 1-\mathrm{p} 2$ measured along the alveoli -23.2 ; length from the mandible symphysis to the alveolus of $\mathrm{m} 2-34.4$ thickness of the body of mandible before $\mathrm{m} 1-3.8$; length and breadth of $\mathrm{m} 1$ at the base of the crown $-4.4 / 3.8$.

Horse is represented in all cultural horizons by the following bone remains: right i3, 13 fragmental teeth, incomplete fused radial and ulnar bones (Fig. 2). Fragments of teeth probably belonged to several neighboring teeth of a tooth row. The radial bone has the following measurements: greatest length -304.2 ; physiological length -293.8 ; length of the lateral part -292.0 ; greatest breadth of the proximal end -72.4 ; greatest breadth of the humeral articular surface -68.15 ; smallest breadth of diaphysis -36.3 ; greatest breadth of the facies articularis distalis - 55.7. The ulnar bone has the following measurements: depth across the processus anconaeus -55.8 ; smallest depth of the olecranon - 45.6; greatest breadth of the proximal articular surface - about 37.9. The tuber olecrani and the olecranon are damaged.

The family Cervidae is represented by the red deer, roe deer, moose, and reindeer. Fragments of the scapula and humerus were not originally identified to species (Nikulina et al., 2018). We obtained measurements on these fragments of deer bones. The scapula has the following measurements: breadth of the glenoid cavity 45.6; length of the glenoid cavity - 47.2; greatest length of the glenoid process -66.4 . The greatest breadth of the distal end of the humerus is 47.2 (Fig. 2). A comparison of these measurements to those of diverse cervids from other sites showed that the scapula belongs to red 
(A)

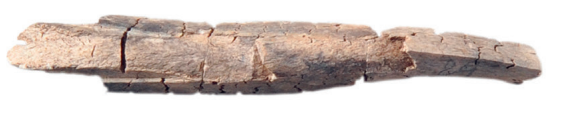

(C)
(B)

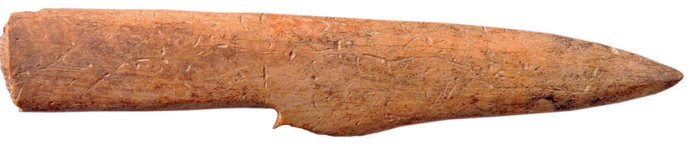

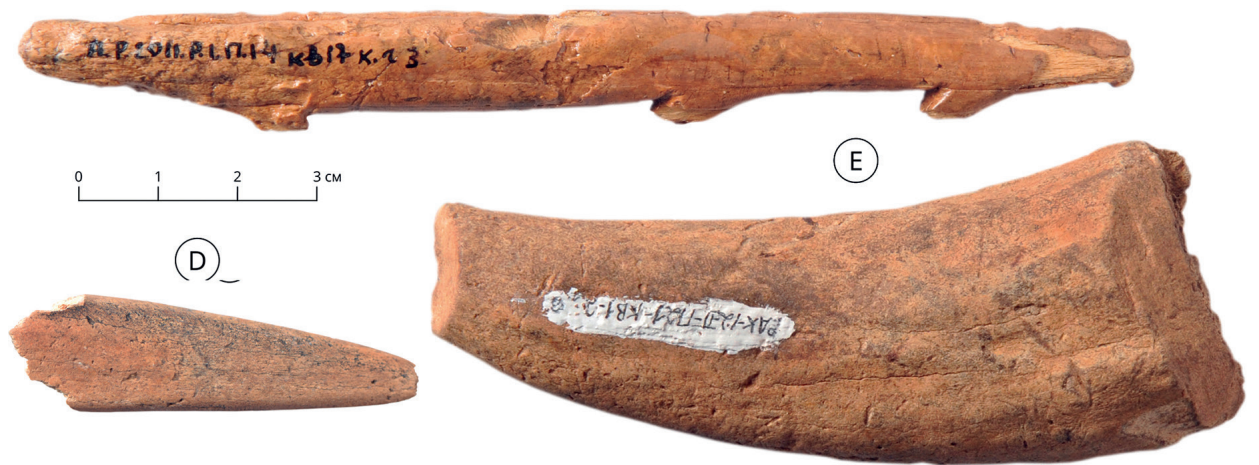

Fig. 3. Bone implements. A - harpoon combined from four burnt fragments; B, D - fragments of harpoons; C - harpoon; E fragment of the antler with cut marks.

deer, and the humerus - to reindeer (Klementiev, 2009; Vasiliev, 2013a). Fragments of the antler and teeth could not be identified. Therefore, they were attributed to Cervidae gen. indet.

Red deer is the most numerous among the family Cervidae. The remains of red deer are represented by antlers, scapula, humerus, femur, vestigial metapodia, calcaneus, astragalus and naviculo-cuboid. Astragalus showed the following measurements: greatest length of the lateral half -72.3 and 69.1 ; greatest length of the medial half -66.4 and 64.9 ; greatest breadth of the distal end -43.6 and 39.45; greatest depth of the lateral half37.8 and 35.7; greatest depth of the medial half $--/ 34.45$.

Siberian roe deer is identified based on the left lower dentition (without p2), a fragment of the base of the skull, two fragments of the scapula, fragments of the epiphysis of the humerus and femur, and a fragment of the phalanx.

As for the moose, it is represented by fragments of teeth, metapodia, and phalanges. Magnum, scaphoid, and triquetrum were also found.

\section{Archaeozoological description}

The first cultural horizon is predominantly represented by indefinable bones ( $86.5 \%)$. Burnt bones accounted for $8.1 \%$. An incomplete harpoon combined from four burnt fragments was found in this cultural horizon (Fig. $3)$. Also this cultural horizon yielded a proximal end of metapodia of the moose with gnaw marks made by carnivores.

The second cultural horizon is represented by the largest number of bones. The share of indefinable bones is $91.4 \%$. Teeth are the most numerous among the identifiable bone remains. Red deer is predominantly represented by long bones and distal bones of append- ages. It is worth noting that the bones of the left hind limb were articulated: the calcaneus with astragalus, and astragalus with naviculo-cuboid. Also three right carpal bones (magnum, scaphoid, and triquetrum) of moose belong to one individual. This cultural horizon yielded antlers of red deer with handling traces. One fragment of the antler shows scraping marks of cancellous tissue, and the other has cut marks (Fig. 3). Burnt bones accounted for $13.8 \%$. They are predominantly represented by indefinable bones. Also two indefinable bones with gnaw marks made by rodents were found in this cultural horizon. In addition, several bone implements and human processed bones were found: two fragments of harpoons and two fragments of ribs of large ungulates with traces of human activity. One fragment of the harpoon was probably broken before burial (Fig. 3). One fragment of the rib was sharpened with pointed end produced by grinding (Fig. 3). The other fragment has cut marks. It was also modified through grinding.

The third cultural horizon is represented by the largest number of indefinable bones (95.9\%). Burnt bones accounted for $1.8 \%$. This cultural horizon yielded a distal end of humerus of the roe deer with gnaw marks made by carnivores. Teeth are the most numerous among the identifiable bone remains. As for bone implements, harpoon made of long bone of a large ungulate was found (Fig. 3). Also two human processed bones were found. One fragment shows a pit, and the other has a cut mark. The latter was also modified through grinding.

We can make only approximate archaeozoological analysis due to the small amount of bones. Bone remains with traces of human activity indicate hunting. The predominance of teeth and distal bones of appendages, and the presence of articulated bones could indicate 
that animals were killed in the immediate vicinity and dismembered at the site. Human processed bones indicate that people spent some time at the site to process the bones. Harpoon fragments and fish scales indicate fishery practiced in all periods of site use. Fish scales are not abundant, which is likely to be attributed to the excavation technique: no wet or dry screening was carried out during the rescue excavations.

\section{Discussion}

The multilayered site Ruchei Akimov is important for the study of the history of the Middle - Late Holocene faunas of the Northern Angara region. We can make only approximate characteristics of the economy of the population of the site due to the small amount of identifiable bones (Antipina, 2016). Though these conclusions are significant in the study of the history of the faunas of the Neolithic - early Middle Ages, because currently the site is completely flooded by the waters of the Boguchany Hydroelectric Power Station.

The identified fauna of Ruchei Akimov is mainly represented by modern species. The only extinct species is the Eurasian beaver. This taxon is present in the cultural horizons of the Neolithic - early Bronze Age and is absent in the cultural horizon of the late Bronze Age - early Middle Ages. The beaver survived in the vicinity of the sites Ust-Yodarma II and Ust-Keul I (Northern Angara Region) until the Iron Age (Klementiev, 2012, 2013). According to Skalon (1951), "in ancient times the beaver was spread throughout Northern Eurasia" and disappeared in Siberia by the time of arrival of the first Russian settlers. It is therefore possible that the beaver also lived in the adjacencies of Ruchei Akimov in the Iron Age. The beaver, most likely, was a trade species at Ruchei Akimov, because this species has been the object of hunting since prehistoric times (Arembovskii, 1937).

All mammals of the cultural horizons of the Neolithic - early Bronze Age are represented by wild animals. We cannot identify horse teeth found in these cultural horizons to wild or domestic form. The largest number of bones in the cultural horizons of the Neolithic - early Bronze Age belongs to the family Cervidae. Siberian roe deer remains outnumber those of red deer in the third cultural horizon, but in the second cultural horizon red deer remains are more abundant than those of roe deer. It indicates the decline of the role of roe deer as the most commonly harvested animal and the switch to red deer as the new hunting priority. Finds of carnivorans are few. Bear is the most abundant carnivoran taxon in the second and third cultural horizons; the remains of sable are rare. The predominance of the brown bear among carnivorans probably indicates that this species was a commonly hunted game in the Holocene of this region (Klementiev \& Novoseltseva, 2013). Sable is also a commonly harvested species for the population of Angara Region in the Neolithic and Bronze Age (Klementiev, 2012). The sable is represented by fewer bones than the brown bear among all bones from Ruchei Akimov.
The dog is identified in the cultural horizon of the late Bronze Age - early Middle Ages. This species was identified based on the left mandible. Length of the alveolus of $\mathrm{m} 1$ and length of the p1-p4 measured along the alveoli indicate that the dog from Ruchei Akimov was smaller than the Mesolithic dog from Ust-Keul I (Klementiev \& Novoseltseva, 2013). The fused radial and ulnar bones of a horse were also identified in the first cultural horizon. Measurements for these bones indicate that this individual was small. Thus, radial and ulnar bones probably belonged to a domestic horse. Bones of wild species also were found in the cultural horizon of the late Bronze Age - early Middle Ages. The predominance of cervids (red deer, moose) indicates their importance in hunting.

A comparison showed the similarity of the fauna of the site Ruchei Akimov to that of other sites in the Northern Angara region. There is a tendency to increasing importance of domestic species (domestic horse, reindeer, cattle, sheep and goats) and decreasing role of trade species (roe deer, moose) in the economy of the sites Ust-Yodarma II and Ust-Keul I during the late Bronze Age - the Middle Ages (Klementiev, 2012; Klementiev \& Novoseltseva, 2013). At the site Ruchei Akimov this tendency is difficult to trace due to the small amount of identifiable bones. It is worth noting the presence of a dog in cultural horizons of the late paleometal period at these three sites of the Northern Angara Region. The bones of hare, which are common at Ust-Yodarma II, and the bones of beaver, fox, bear, badger, which are rare at Ust-Ydarma II and Ust-Keul I, are absent in the cultural horizon of the late Bronze Age - early Middle Ages at Ruchei Akimov (Klementiev, 2012; Klementiev \& Novoseltseva, 2013).

The majority of bone remains from the Neolithic cultural horizons of sites of Northern Angara region are from cervids, with moose being most abundant at the sites Ust-Yodarma II, Ust-Keul I, Ust-Tushama I (Klementiev, 2012; Klementiev \& Novoseltseva, 2013; Vasiliev, 2013b). Though the ratio of roe deer and moose in the hunting is equalized by the end of the Neolithic at Ust-Keul I (Klementiev \& Novoseltseva, 2013). Bone remains of roe deer are most abundant at the site Ostrov Listvenichnyi. It is untypical for the nearby archaeological sites of the early Neolithic period (Klementiev et al., 2017). We could not find detailed data of the faunal assemblages of other sites of the Northern Angara region. It is only known that moose, bear, and deer are the most numerous at the sites Pashina, Koda, and Chadobets during the Neolithic, and the bones of red deer, roe deer, and reindeer were found at the sites Badarma I and Ust-Kova (Vasil'evskii et al., 1988). According to new data, moose, reindeer, and roe deer are the most abundant species at Pashina (Grishin et al., 2016). Reindeer is represented by a single fragment of the humerus at Ruchei Akimov. At the same time, reindeer is the second numerous in the Neolithic horizon at Ust-Tushama I, being inferior only to a moose (Vasiliev, 2013b). It is also worth noting the absence of mole, hare, wolf, dog, fox, badger, otter, boar, and bison in the Neolithic cultural horizons at Ruchei 
Akimov. Few faunal remains of these species were found in the previously mentioned sites (Klementiev, 2012; Klementiev \& Novoseltseva, 2013; Klementiev et al., 2017; Vasiliev, 2013b; Vasil'evskii et al., 1988). It may be related to small amount of faunal material.

\section{Conclusions}

The fauna of the site Ruchei Akimov is similar to that of other sites in the Northern Angara region. The first cultural horizon of the late Bronze Age - early Middle Ages yielded small amount of faunal material. Thus, we can make only preliminary results on bone remains from this cultural horizon. The fauna from Ruchei Akimov in the Neolithic - early Bronze Age consisted primarily of red deer, moose, and roe deer. Cervidae gen. indet. is the fourth most abundant group of mammals in the Neolithic - early Bronze Age. It is worth noting the presence of horse in cultural horizons of Neolithic - early Bronze Age. Bone remains of Equus caballus/ferus are the fourth numerous in the Neolithic layer at Ust-Tushama I (Vasiliev, 2013b). There are fragments of the horse teeth found in the Neolithic horizon at habitation site Pashina, but they are associated with the medieval population or the later Russian presence (Grishin et al., 2016). Bone remains of a horse of the Neolithic age are not mentioned at other sites of the Northern Angara region. Thus, the predominance of red deer and the presence of horse in the Neolithic - early Bronze Age are distinctive features of the site Ruchei Akimov. More accurate chronological assessment of the Equus sp. will be possible after radiocarbon dating and isotopic analysis. Results of archaeozoological analysis suggest hunting and fishery practiced in all periods of site use. Most probably animals were killed in the immediate vicinity and dismembered at the site.

ACKNOWLEDGEMENTS. Scientific Research Center «Baikal Region» is thanked for providing faunal material from the multilayered site Ruchei Akimov. We thank the reviewers for helpful suggestions. The study of collection was supported by the grant from the Government of the Russian Federation, the project No. 075-15-2019-866 «Baikal Siberia in the Stone Age: at the crossroads of the worlds». Data collecting for the morphological part of the study was supported by the Russian Foundation for Basic Research, project No. 18-05-00746.

\section{References}

Antipina E.E. 2016. [Modern archeozoology: research objects and methods] // Mezhdistsiplinarnaya integratsiya $\mathrm{v}$ arkheologii (po materialam lektsii dlya aspirantov i molodykh uchenykh. P.96-117 [in Russian].

Arembovskii I.V. 1937. [Eurasian beaver in the past of Eastern Siberia] // Izvestiya Irkutskogo Gosudarstvennogo Nauchnogo Muzeya. Vol.2. No.57. P.118-127 [in Russian].
Grishin A.E., Marchenko J.V., Garkusha Yu.N., Gurulev D.A., Schneider S.V., Kulik N.A., Vasiliev S.K. \& Kerbs E.A. 2016. [The Habitation Site Pashina in the Northern Angara Region (2008-2009 research)]. Novosibirsk: Izdatel'stvo IAET SB RAS. 168 p. [In Russian].

Klementiev A.M. 2009. [Remains of large mammals from the Bratsk reservoir (Unga-Osinskoe expansion): preliminary data] // Yeniseyskaya Provintsiya. Al'manakh. No.4. P.91-102 [in Russian].

Klementiev A.M. 2012. [Preliminary data of the Holocene fauna of Northern Angara Region (materials of site Ust-Yodarma-II)] // Medvedev G.I. (ed.). Evraziya v kainozoye. Stratigrafiya, paleoekologiya, kul'tury. Irkutsk: Izdatel'stvo IGU. No.1. P.94-105 [in Russian, with English summary].

Klementiev A.M. \& Novoseltseva V.M. 2013. [Fauna of geoarchaeological object Ust-Keul I (Northern Angara Region)] // Izvestiya Irkutskogo Gosudarstvennogo Universiteta. Seriya Geoarkheologiya. Etnologiya. Antropologiya. No.2 (3). P.3-14 [in Russian, with English summary].

Klementiev A.M., Kuznetsov A.M. \& Rogovskoi E.O. 2017. [Archaeozoological studies of multilayered site Ostrov Listvenichnyi (Northern Angara Region)] // Izvestiya Irkutskogo Gosudarstvennogo Universiteta. Seriya Geoarkheologiya. Etnologiya. Antropologiya. Vol.22. P.82-101 [in Russian, with English summary].

Lyudnikov V.O. 2012. ["Cache" of stone items from the site Ruchei Akimov (Northern Angara)] // Tumen D., Erdene M. \& Mizhiddorzh E. (eds.). Drevniye kul'tury Mongolii i Baikal'skoi Sibiri: materialy III mezhdunarodnoi nauchnoi konferentsii. Ulan Bator: Izdatel'stvo Mongol'skogo gosudarstvennogo universiteta. Vol.1. P.61-67 [in Russian, with English summary].

Nikulina E.D., Burova V.V. \& Tolstova M.V. 2018. [The review of the faunal collection from the multilevel location Ruchei Akimov (Northern Angara Region) after the excavation in 2011-2012] // Podobina V.M. (ed.). Evolyutsiya zhizni na Zemle: materialy $\mathrm{V}$ mezhdunarodnogo simpoziuma. Tomsk: Izdatel'skii Dom Tomskogo gosudarstvennogo universiteta. P.220-222 [in Russian, with English summary].

Skalon V.N. 1951. [Eurasian Beavers of Northern Asia]. Moscow: Izdatel'stvo MOIP. 208 p. [In Russian].

Tolstova M.V. 2016. [Deposit of stone arrowheads from the site Ruchei Akimov] // Konstantinov A.V. \& Razgil'deeva I.I. (eds.). Materialy LVI Rossiiskoi arkheologo-etnograficheskoi studencheskoi konferentsii. Chita: Zabaikal'skii gosudarstvennyi universitet. P.100-102 [in Russian, with English summary].

Tolstova M.V. \& Lokhov D.N. 2017. [Ceramic complexes of the Neolithic epoch of the site Ruchei Akimov (Northern Angara region)] // Berdnikov I.M. \& Lipnina E.A. (eds.). Yevraziya $\mathrm{v}$ kainozoye. Stratigrafiya, paleoekologiya, kul'tury. Irkutsk: Izdatel'stvo IGU. No.6. P.240-247 [in Russian, with English summary].

Vasiliev S.K. 2013a. [Red deer (Cervus elaphus cf. sibiricus) in the southern part of Western and Central Siberia during the late Pleistocene and Holocene] // Zoologicheskii Zhurnal. Vol.92. No.9. P.1031-1045 [in Russian, with English summary].

Vasiliev S.K. 2013b. [The Irish elk (Megaloceros giganteus Blumenbach, 1803) in the paleofauna of the Holocene 
sites of the Northern Angara Region (Ust-Tushama-1, Sosnovy Tushamsky ostrov, Ust-Talaya)] // Vestnik NGU. Seriya: Istoriya, filologiya. Vol.12. No.7: Arkheologiya i Etnografiya. P.177-185 [in Russian, with English summary].
Vasil'evskii R.S., Burilov V.V. \& Drozdov N.I. 1988. [Archaeological Sites of the Northern Angara Region]. Novosibirsk: Nauka. 224 p. [In Russian].

Von den Driesch A. 1976. A Guide to the Measurement of Animal Bones from Archaeological Sites. Cambridge: Peabody Museum Press. 136 p. 